\title{
PERAN KEMAMPUAN KOMUNIKASI MATEMATIKA TERHADAP PRESTASI BELAJAR MATEMATIKA SISWA
}

\author{
ANGGRAINI ASTUTI \\ anggrainiastuti49@yahoo.com \\ Program Studi Pendidikan Matematika, Fakultas Teknik, Matematika dan IPA \\ Universitas Indraprasta PGRI
}

LEONARD

leoanova@yahoo.com

Program Studi Pendidikan Matematika, Fakultas Teknik, Matematika dan IPA Universitas Indraprasta PGRI

\begin{abstract}
Abstrak. Penelitian ini bertujuan untuk mengetahui tentang pengaruh kemampuan komunikasi matematika terhadap prestasi belajar matematika siswa SMP di Jakarta. Metode penelitian yang digunakan adalah survei. Populasi penelitian ini adalah seluruh siswa di Penjaringan, Jakarta Utara. Sampel diambil dengan teknik simple random sampling, sebanyak 34 orang siswa. Instrumen yang digunakan adalah instrumen kemampuan komunikasi matematika siswa dan instrumen prestasi belajar matematika. Data dianalisis dengan teknik korelasi regresi. Hasil pengujian hipotesis menunjukkan bahwa terdapat pengaruh positif dan signifikan kemampuan komunikasi matematika terhadap prestasi belajar matematika.
\end{abstract}

Keywords: matematika, hasil belajar, kemampuan komunikasi matematika

\begin{abstract}
The aim of this research is to know the influence of mathematical communication skills of the students toward the learning result (achievement) in junior high school in Jakarta. The research method which was used in the research is survey method. The population of research is all students in junior high school in Penjaringan, north Jakarta. Samples are taken by simple random sampling, consisted of 34 students. The research instrument is mathematical communication skills of the students and mathematics learning achievement. Data analysis employed regretion correlation. The hypothesis testing resulted conclution: there positive correlation of mathematical communication skills of the students toward the mathematics learning achievement.
\end{abstract}

Keywords: mathematics, achievement, mathematical communication skills

\section{PENDAHULUAN}

Pendidikan merupakan segala situasi hidup yang mempengaruhi pertumbuhan individu sebagai pengalaman belajar yang berlangsung dalam segala lingkungan dan sepanjang hayat. Salah satu lingkungan pendidikan yang sengaja dirancang untuk melaksanakan pendidikan adalah sekolah. Seperti yang dikatakan Tirtarahardja (2005: 173) bahwa sekolah seharusnya menjadi pusat pendidikan untuk menyiapkan manusia Indonesia sebagai individu, warga masyarakat, warga Negara, dan warga dunia di masa depan, sehingga sekolah diharapkan mampu melaksanakan fungsi pendidikan secara optimal, yakni mengembangkan kemampuan serta meningkatkan mutu kehidupan dan martabat manusia Indonesia dalam rangka mewujudkan tujuan nasional. 
Namun kenyataannya mutu pendidikan di Indonesia sampai saat sekarang ini masih sangat rendah dibandingkan dengan negara yang lain. Menurut survei Political and Economic Risk Consultant (PERC), kualitas pendidikan di Indonesia berada pada urutan ke-12 dari 12 negara di Asia. Posisi Indonesia berada di bawah Vietnam. Data yang dilaporkan The World Economic Forum Swedia (2000), Indonesia memiliki daya saing yang rendah, yaitu hanya menduduki urutan ke-37 dari 57 negara yang disurvei di dunia.

Rendahnya mutu pendidikan ini mungkin karena pengajaran disajikan masih dalam bentuk yang kurang menarik, sehingga terkesan angker, sulit, dan menakutkan sehingga siswa sering tidak menguasai konsep dasar yang terkandung dalam materi pelajaran matematika yang dapat mengakibatkan kesalahan fatal terhadap keberhasilan belajar siswa sehingga hasil belajar siswa menjadi rendah.

Menurut Muliawan (2012: 51) "Matematika yang dipelajari disekolah termasuk ilmu pengetahuan murni yang mengandalkan angka-angka, simbol, dan lambang." Pada umumnya, selama ini pembelajaran matematika lebih difokuskan pada aspek komputasi yang bersifat algoritmik. Tidak mengherankan bila berdasarkan berbagai studi menunjukkan bahwa siswa pada umumnya dapat melakukan berbagai perhitungan matematik, tetapi kurang menunjukkan hasil yang menggembirakan terkait penerapannya dalam kehidupan sehari-hari.

Salah satu masalah penting dalam pembelajaran matematika saat ini adalah pentingnya pengembangan kemampuan komunikasi matematika siswa. Pengembangan komunikasi juga menjadi salah satu tujuan pembelajaran matematika dan menjadi salah satu standar kompetensi lulusan dalam bidang matematika. Melalui pembelajaran matematika, siswa diharapkan dapat mengkomunikasikan gagasan dengan simbol, tabel, diagram, atau media lain untuk memperjelas keadaan atau masalah. Yamin (Musfiqon, 2012: 17) mengatakan, "komunikasi antara siswa dengan guru adalah penyampaian pesan (materi) pelajaran. Di dalamnya terjadi dan terlaksana hubungan timbal balik (komunikatif). Guru menyampaikan pesan (message), siswa menerima pesan dan kemudian bertanya kepada guru. Atau sebaliknya guru yang bertanya kepada siswa dalam pembelajaran."

Komunikasi memainkan peranan yang penting dalam membantu siswa bukan saja dalam membina konsep melainkan membina perkaitan antara ide dan bahasa abstrak dengan simbol matematika. Siswa juga harus diperkenankan mempersembahkan ide-ide mereka secara bertutur, menulis, melukis gambar atau grafik. Komunikasi membuka ruang kepada siswa untuk berbincang dan berdiskusi tentang matematika. Jadi jika siswa memiliki kemampuan komunikasi yang baik kemungkinan besar hasil belajar siswa dalam pembelajaran matematika pun akan baik pula.

\section{TINJAUAN PUSTAKA}

\section{Kemampuan Komunikasi Matematika}

Menurut Musfiqon (2012:16) "Komunikasi merupakan kegiatan rutin setiap interaksi antara dua orang atau lebih. Pada hakekatnya setiap kegiatan untuk memindahkan ide atau gagasan dari satu pihak ke pihak lain, baik itu antar manusia, antara manusia dengan alam sekitarnya atau sebaliknya, di situ akan terjadi proses komunikasi”. Komunikasi disini melibatkan komunikator yang menyampaikan pesan kepada komunikan yang langsung memberikan respons secara aktif.

Musfiqon (2012: 25) berpendapat, "unsur-unsur komunikasi dalam pembelajaran terdiri dari: guru, siswa, materi pelajaran, tujuan pembelajaran, media dan evaluasi". Selanjutnya, menurut Raymond S. Ross (Mulyana, 2007:69) "Komunikasi adalah suatu proses memilih dan mengirimkan simbol-simbol sedemikian rupa sehingga membantu 
pendengar membangkitkan makna atau respons dari pikirannya yang serupa dengan yang dimaksudkan komunikator".

Komunikasi merupakan bentuk pelemparan pesan atau lambang yang mau tidak mau akan menimbulkan pengaruh pada proses umpan balik, sebab dengan adanya umpan balik, sudah membuktikan adanya jaminan bahwa pesan telah sampai pada pendengar. Menurut Armiati (2003: MP-18), "komunikasi matematis adalah suatu keterampilan penting dalam matematika yaitu kemampuan untuk mengekspresikan ide-ide matematika secara koheren kepada teman, guru, dan lainnya melalui bahasa lisan dan tulisan".Dengan menggunakan bahasa matematika yang benar untuk berbicara dan menulis tentang apa yang mereka kerjakan, mereka akan mampu mengklarifikasi ide-ide mereka dan belajar bagaimana membuat argument yang meyakinkan dan mempresentasikan ide-ide matematika.

Kemampuan komunikasi seharusnya meliputi berbagi pemikiran, menanyakan pertanyaan, menjelaskan pertanyaan dan membenarkan ide-ide. Komunikasi harus terintegrasi dengan baik pada lingkungan kelas. Siswa harus didorong untuk menyatakan dan menuliskan dugaan, pertanyaan dan solusi. Sumarmo (Syaban, 2009), komunikasi matematis meliputi kemampuan siswa: (1) menghubungkan benda nyata, gambar, dan diagram ke dalam idea matematika; (2) menjelaskan ide, situasi dan relasi matematik secara lisan atau tulisan dengan benda nyata, gambar, grafik dan aljabar; (3) menyatakan peristiwa sehari-hari dalam bahasa atau simbol matematika; (4) mendengarkan, berdiskusi, dan menulis tentang matematika; (5) membaca dengan pemahaman atau presentasi matematika tertulis; (6) membuat konjektur, menyusun argumen, merumuskan definisi dan generalisasi; (7) menjelaskan dan membuat pertanyaan tentang matematika yang telah dipelajari.

Pentingnya kemampuan komunikasi sebagai hasil belajar, tertuang dalam salah satu kompetensi lintas kurikulum yang merupakan bagian dari kurikulum berbasis kompetensi (Ratumanan, 2003:29), yakni siswa menggunakan bahasa untuk memahami, mengembangkan, dan mengkomunikasikan gagasan dan informasi, serta untuk berinteraksi dengan orang lain. Berkaitan dengan kemampuan komunikasi matematika, Depdiknas (Ratumanan, 2003:29) mengemukakan bahwa "Kompetensi matematika yang harus dimiliki siswa SD, SLTP, dan SMA, salah satu diantaranya yang termasuk dalam keterampilan matematika adalah kemampuan mengkomunikasikan gagasan dengan simbol, tabel, grafik atau diagram untuk memperjelas keadaan atau masalah".

Berdasarkan pendapat-pendapat di atas dapat disimpulkan bahwa kemampuan komunikasi matematika adalah kemampuan siswa untuk merepresentasikan permasalahan atau ide dalam matematika dengan menggunakan benda nyata, gambar, grafik, atau tabel, serta dapat menggunakan simbol-simbol matematika.

\section{Prestasi Belajar Matematika}

Slameto (2003: 2) menyatakan, "belajar adalah suatu proses usaha yang dilakukan seseorang untuk memperoleh suatu perubahan tingkah laku yang baru secara keseluruhan, sebagai hasil pengalamannya sendiri dalam interaksi dengan lingkungannya". Usaha seseorang dalam mencapai sesuatu hal berkaitan dengan usahanya untuk belajar, dengan belajar maka seseorang memperoleh perubahan tingkah laku. Belajar bukan berarti membaca buku pelajaran tetapi belajar yang dimaksud di sini yaitu dari pengalaman kita bisa belajar dari kegagalan.

Menurut Tirtarahardja (2005:128), "belajar adalah perubahan perilaku yang relatif tetap karena pengaruh pengalaman". Menurut pengertian ini, belajar adalah suatu proses kegiatan dan bukan hasil atau tujuan. Belajar tidak hanya mengingat, akan tetapi lebih luas daripada itu, yakni mengalami. Lebih jauh Musfiqon (2012:5) berpendapat 
bahwa, "belajar dapat didefinisikan sebuah proses interaksi antara manusia dengan lingkungan yang dilakukan secara terencana untuk mencapai pemahaman, keterampilan, dan sikap yang diinginkan sehingga terjadi perubahan pada diri seseorang dari hasil belajar tersebut, yaitu kedewasaan diri". Belajar merupakan aktivitas terencana untuk mendapatkan pengetahuan dan wawasan, agar perilaku seseorang berubah menuju pada kedewasaan. Pemahaman yang telah didapat menjadi sumber nilai yang mempengaruhi seseorang dalam berpikir, bertindak, dan berperilaku.

Belajar merupakan suatu proses internal yang kompleks, belajar merupakan proses internal siswa yang tidak dapat diamati secara langsung oleh guru, tetapi dapat dipahami oleh guru melalui perilaku siswa yang mempelajari bahan belajar. Menurut Arifin (2009: 12) "Prestasi belajar merupakan suatu masalah yang bersifat perennial dalam sejarah kehidupan manusia, karena sepanjang rentang kehidupannya manusia selalu mengejar prestasi menurut bidang dan kemampuan masing-masing”. Dari teori di atas maka pengertian prestasi belajar itu adalah ilmu pengetahuan yang diperoleh dalam proses belajar yang dihasilkan dari tes beberapa bidang studi sehingga mendapatkan hasil/skor.

Betapa pentingnya seorang pengajar mengetahui dan memahami prestasi belajar peserta didik, baik secara perseorangan maupun secara kelompok, sebab fungsi prestasi belajar tidak hanya sebagai indikator keberhasilan dalam bidang studi tertentu, tetapi juga sebagai indikator kualitas institusi pendidikan. Arifin (2009:13) berpendapat lain bahwa "Prestasi belajar juga bermanfaat sebagai umpan balik bagi guru dalam melaksanakan proses pembelajaran sehingga dapat menentukan apakah perlu melakukan diagnosis, penempatan, atau bimbingan terhadap peserta didik". Hasil penilaian dari evaluasi merupakan umpan balik untuk mengukur sampai dimana keberhasilan proses belajar mengajar. Dengan nilai-nilai yang diperoleh siswa, guru pun akan mengetahui sejauh mana keberhasilannya dalam mengajar, dan hal itu dapat digunakan untuk perbaikan dalam proses pembelajaran berikutnya.

Matematika sebagai ilmu pengetahuan murni dengan menggunakan aneka angka dan lambang serta hubungan antara bilangan dan prosedur operasional yaitu meliputi penambahan, pengurangan, perkalian dan pembagian. Menurut Sujono (Abdul Halim Fathani, 2009:19) mengemukakan pengertian matematika yaitu "Matematika merupakan ilmu pengetahuan tentang penalaran yang logic dan sebagai ilmu bantu dalam menginterpretasikan berbagai ide dan kesimpulan".

Matematika dipandang sebagai cara bernalar karena memuat cara pembuktian yang sahih, rumus-rumus atau aturan yang umum atau sifat penalaran matematika yang sistematis. Maka matematika terbentuk sebagai hasil pemikiran manusia yang berhubungan dengan ide, proses, dan penalaran. Suriasumantri (2005:190) menyatakan, "matematika adalah bahasa yang melambangkan serangkaian makna dari pernyataan yang ingin kita sampaikan. Lambang-lambang matematika bersifat "artifisial" yang baru mempunyai arti setelah sebuah makna diberikan kepadanya. Tanpa itu maka matematika hanya merupakan kumpulan rumus-rumus yang mati”. Matematika berguna untuk melatih daya fikir seseorang, yang membuatnya kreatif dalam memecahkan masalahmasalah. Matematika secara tidak langsung menjadi tujuan dan bukan alat itu sendiri, karena cabang ilmu pengetahuan lain menggunakan dan juga tergantung terhadap matematika.

Prestasi belajar matematika merupakan bukti keberhasilan yang telah dicapai setelah proses belajar mengajar matematika terjadi. Dalam mencapai prestasi belajar matematika yang baik, seorang siswa dipengaruhi oleh berbagai faktor, baik dari dalam diri siswa maupun dari luar diri siswa. Menurut Ahmadi (2004: 138) "Faktor-faktor yang mempengaruhi prestasi belajar siswa secara garis besar terbagi dua yaitu: 1) Yang 
tergolong faktor internal adalah: faktor jasmaniah (fisiologi) dan faktor psikologis. 2) Yang tergolong faktor eksternal adalah: faktor sosial, faktor budaya, dan faktor lingkungan fisik.

Jadi, dapat disimpulkan bahwa prestasi belajar matematika adalah hasil yang diperoleh siswa dari proses pembelajaran matematika yaitu meliputi proses perubahan tingkah laku yang menghasilkan perubahan-perubahan dalam pengetahuan terutama penguasaan bahan belajar matematika.

\section{METODE}

Penelitian dilaksanakan di Sekolah Menengah Pertama di Penjaringan, Jakarta Utara. Tepatnya di SMP Wijayakusuma Jakarta. Pelaksanaan penelitian dilaksanakan dalam waktu lima bulan pada tahun 2012.

Metode yang digunakan dalam penelitian ini adalah metode survei dengan teknik analisis korelasi regresi. Populasi dalam penelitian ini adalah siswa-siwi SMP Wijayakusuma Jakarta kelas VIII. Sampel diambil dari populasi terjangkau dengan teknik simple random sampling secara bertahap. Dalam penelitian ini, jumlah populasi siswa SMP Wijayakusuma kelas VIII sebanyak 108 siswa dan tingkat presisi yang ditetapkan sebesar 15\%, maka akan diperoleh sampel sebanyak 34 responden.

Pengumpulan data untuk variabel prestasi belajar matematika diperoleh dari hasil tes ulangan akhir semester genap yang diberikan kepada siswa dan datanya diperoleh dari wali kelas (data sekunder). Tes prestasi berupa pilihan ganda sebanyak 40 soal. Sedangkan untuk variabel kemampuan komunikasi matematika diperoleh dengan melakukan tes tertulis yang berupa soal essai kepada sampel atau responden sebanyak 10 butir soal.

\section{HASIL DAN PEMBAHASAN}

Data Prestasi Belajar Matematika

Dari hasil pengukuran prestasi belajar matematika terhadap 34 siswa yang dijadikan sampel penelitian, diperoleh data skor maksimum 27 dan skor minimum 11, sehingga diperoleh rentang (jangkauan) data sebesar 16. Berdasarkan hasil analisis data, diperoleh mean 20,29; median 20,59; modus 20,3; dan simpangan baku 4,18. Dari rentang skor teoritik antara 11 sampai 27 , mayoritas siswa $(32,4 \%)$ memiliki skor prestasi belajar matematika dalam rentang antara 20 sampai 22 dari skor maksimum 27. Dengan demikian dapat dikatakan bahwa prestasi belajar matematika siswa tergolong baik dan tidak banyak beragam.

\section{Data Kemampuan Komunikasi Matematika}

Dari hasil pengukuran kemampuan komunikasi matematika terhadap 34 siswa yang dijadikan sampel penelitian, diperoleh data skor maksimum 100 dan skor minimum 42, sehingga diperoleh rentang (jangkauan) data sebesar 58. Berdasarkan hasil analisis data, diperoleh mean 77,38; median 78,5; modus 78,64; dan simpangan baku 14,22. Dari rentang skor teoritik antara 42 sampai 100 , mayoritas siswa $(29,4 \%)$ memiliki skor prestasi belajar matematika dalam rentang antara 72 sampai 81 dari skor maksimum 100 . Dengan demikian dapat dikatakan bahwa kemampuan komunikasi matematika siswa tergolong baik dan tidak banyak beragam.

\section{Uji Persyaratan Analisis Data}

Data yang telah dikumpulkan selanjutnya diuji persyaratan analisis, yang meliputi uji normalitas dan uji linieritas. Hasil pengujian normalitas menggunakan menggunakan uji Chi Kuadrat diperoleh hasil bahwa seluruh variabel berdistribusi 
normal. Hasil pengujian linieritas menggunakan tabel bantuan ANAVA diperoleh hasil bahwa persamaan regresi yang terbentuk antara kedua variabel adalah linier, sehingga dapat dilanjutkan menggunakan statistik parametrik, dengan korelasi dan regresi linier sederhana.

\section{Pengujian Hipotesis Penelitian}

Untuk mengetahui tingkat keeratan hubungan antara variabel $\mathrm{X}$ dan variabel $\mathrm{Y}$ dalam penelitian ini digunakan rumus Korelasi Product Moment. Dari perhitungan didapat nilai $\mathrm{r}_{\mathrm{xy}}=0,94$. Artinya, terdapat hubungan yang sangat kuat antara kemampuan komunikasi matematika dengan prestasi belajar matematika siswa.

Pengujian signifikansi koefisien korelasi antara variabel $\mathrm{X}$ dan variabel $\mathrm{Y}$ dalam penelitian ini diuji melalui uji hipotesis (uji t). Dari hasil perhitungan, didapat $\mathrm{t}_{\text {hitung }}=$ 15,44; sedangkan $t_{\text {tabel }}=2,04$ pada taraf nyata 95\%. Dari hasil ini dapat disimpulkan bahwa terdapat hubungan yang signifikan antara kemampuan komunikasi matematika dengan prestasi belajar matematika.

Untuk mengetahui besarnya kontribusi pengaruh kemampuan komunikasi matematika terhadap prestasi belajar matematika siswa dilakukan dengan menghitung koefisien determinasi. Dari perhitungan didapat koefisien determinasi sebesar 88,17\%, atau dapat diartikan bahwa pengaruh kemampuan komunikasi matematika terhadap prestasi belajar matematika sebesar $88,17 \%$ dan sisanya dipengaruhi faktor lain.

Persamaan regresi yang terbentuk adalah $\mathrm{Y}=0,94+0,25 \mathrm{X}$, yang dapat diartikan jika kemampuan komunikasi matematika diabaikan maka prestasi belajar siswa sebesar 0,94; dan setiap penambahan 1 point pada kemampuan komunikasi matematika, akan menambah prestasi belajar matematika sebesar 0,25 point.

Untuk pengujian keberartian regresi dilakukan dengan uji $\mathrm{F}$ untuk taraf nyata $\alpha=$ $5 \%$ dk pembilang $=1$, dk penyebut $=34-2=32$ diperoleh $F_{\text {tabel }}=4,15$ dan $F_{\text {hitung }}=6,40$. Karena $\mathrm{F}_{\text {hitung }}>\mathrm{F}_{\text {tabel }}$ maka Ho ditolak dan $\mathrm{H} 1$ diterima, yang berarti koefisien regresi yang terbentuk dari kemampuan komunikasi matematika terhadap prestasi belajar matematika adalah signifikan.

\section{Pembahasan Hasil Penelitian}

Berdasarkan hasil penelitian dan hasil pengujian hipotesis, maka terbukti bahwa terdapat pengaruh positif kemampuan komunikasi matematika terhadap prestasi belajar matematika. Hal ini menunjukkan bahwa prestasi belajar siswa akan semakin baik jika kemampuan komunikasi matematika ditingkatkan. Berdasarkan fakta tersebut, dapat dikatakan bahwa sebenarnya untuk meningkatkan prestasi belajar siswa harus terlebih dahulu meningkatkan kemampuan komunikasi matematika siswa.

Penelitian Tammi (2010) yang berjudul "pengaruh kemampuan komunikasi matematika terhadap hasil belajar matematika" menemukan bahwa pada kelompok siswa yang memiliki kemampuan komunikasi tinggi memberikan hasil belajar yang tinggi pula. Sebaliknya pada kelompok siswa yang memiliki kemampuan komunikasi rendah memberikan hasil belajar yang rendah pula. Hal ini membuktikan bahwa prestasi belajar tergantung dari tingkat kemampuan komunikasi matematika siswa, artinya besar atau kecil tingkat kemampuan komunikasi siswa, secara signifikan meningkatkan prestasi belajar siswa, atau dengan kata lain prestasi belajar siswa tinggi.

Maka dalam penelitian ini guru matematika harus menciptakan metode belajar yang baik bagi siswa agar dapat dilakukan pemilahan dan perlakuan yang tepat dalam proses kegiatan pembelajaran matematika pada khususnya materi tentang lingkaran dan geometri ruang. Hasil penelitian menunjukkan bahwa secara umum teknik guru dalam meningkatkan kemampuan komunikasi matematika siswa memberikan kontribusi 
perolehan prestasi belajar matematika pada kompetensi dasar lingkaran dan bangun ruang yang lebih baik. Maka dalam implikasi dalam upaya peningkatan prestasi belajar matematika, hendaknya para guru dan pihak sekolah perlu menerapkan teknik dalam proses kegiatan belajar matematika agar kualitas pendidikan dapat terlaksana dengan baik.

Tugas mendidik merupakan tuntutan profesi seorang guru, khususnya bagi anak usia sekolah dasar dan menengah. Karena pada saat itulah terjadi pembentukan karakter dari peserta didik, mereka kebanyakan mencari panutan dari orang yang dekat dengannya. Jadi karena kebanyakan interaksi siswa itu di sekolah maka seharusnya guru memainkan perananya dalam mendidik siswa itu. Pemberian pemahaman materi dasar bidang studi khususnya matematika pada anak didik itu., merupakan satu aspek dari cara meningkatkan kemampuan komunikasi matematika, dan aspek lainnya yang terkait dengan mendidik siswa.

Menurut Tammi (2010), aspek lain yang dapat dilakukan seorang pendidik untuk meningkatkan kemampuan komunikasi matematika siswa dalam menunjang prestasi belajar, yaitu: 1) Mengembangkan pemahaman dasar matematika siswa termasuk aturanaturan definisi matematika, 2) Membuat model dari suatu situasi melalui tulisan, bendabenda konkret, gambar, grafik, dan metode-metode aljabar, 3) Menyusun refleksi dan membuat klarifikasi tentang ide-ide matematika, 4) Menggunakan kemampuan memabaca, menyimak, dan mengamati untuk menginterpretasi dan mengevaluasi suatu ide matematika, 5) Mendiskusikan ide-ide, membuat konjektur, menyusun argument, merumuskan definisi, dan generalisasi, dan 6) Mengapresiasi nilai-nilai dari suatu notasi matematis termasuk aturan-aturannya dalam mengembangkan ide matematika.

Selain pendidik, unsur lain dalam menunjang prestasi belajar yaitu terdapat pada diri siswa itu sendiri, seberapa besar kemauan siswa dalam meningkatkan kemampuan komunikasinya. Armiati (2003: MP-20) menyebutkan beberapa cara yang dapat dilakukan seorang siswa untuk meningkatkan kemampuan komunikasinya, yaitu: 1) Menjadi aktif dan self-directed, 2) Membuat hubungan yang lebih bermakna dengan pengalaman dan pengetahuan sebelumnya, 3) Mengidentifikasi apa yang perlu mereka ketahui untuk diproses, 4) Mengevaluasi proses dan solusi untuk menyatakan apakah proses dan solusi yang diberikan cocok dan masuk akal, 5) Berbagi informasi tentang pengetahuan, prosedur dan strategi yang mendasari kesimpulan mereka, 6) Menyajikan masalah, dan 7) Mengkreasikan alternatif cara lain untuk penyelesaian.

Dengan kemampuan komunikasi yang dimiliki siswa maka siswa dapat memecahkan masalah matematika dengan menggunakan bahasa sehari-hari sebagai bentuk komunikasi dengan orang lain (teman sekelas), terlebih lagi dengan menggunakan simbol dan kosakata matematika secara benar dan lancar merupakan bagian penting dalam pembelajaran matematika. Namun sebagian besar siswa pada umumnya enggan untuk mengadakan pembicaraan mengenai matematika kecuali untuk tujuan menyelesaikan tugas-tugas yang diberikan gurunya. Dalam perspektif ini pun, banyak siswa yang hanya mengikuti jalan pikiran atau bahkan meniru penyelesaian soal dari teman sekelas yang dianggap mampu atau pintar. Maka sebagi guru tuhas yang utama untuk meningkatkan kemampuan komunikasi matematika yaitu dengan mengetahui dan manganalisa siswa yang kurang kreatif dan kurang mampu dalam menguasai pelajaran, sehingga guru dapat mengarahkan dan membimbing siswa ke arah yang lebih baik.

Dalam pengujian hipotesis pada taraf signifikan 5\% diperoleh $t_{\text {hitung }}>t_{\text {tabel }}$ $(15,44,85>2,042)$, maka Ho di tolak dan $\mathrm{H}_{1}$ diterima. Dengan demikian hipotesis teruji kebenarannya dan secara signifikan diterima. Dengan demikian disimpulkan pula bahwa terdapat pengaruh kemampuan komunikasi matematika terhadap prestasi belajar matematika. 
Berdasarkan analisis yang dilakukan oleh Hanun (2009:97) tentang kemampuan siswa dalam menyatakan peristiwa sehari-hari dalam bahasa atau simbol matematika, tampak bahwa siswa dapat menyatakan suatu masalah matematika dengan menggunakan bahasa sendiri atau menerjemahkan ke dalam model matematika dan mengalami proses belajar yang positif. Ini terlihat dari siswa yang berusaha sendiri saat menemui kesulitan dalam menyusun atau menjawab soal meningkat $6,59 \%$ dari $17,8 \%$ menjadi $24,39 \%$, yang meminta bantuan teman meningkat dari $17,08 \%$ atau dari $41,46 \%$ menjadi $58,54 \%$ sedangkan yang minta pada bantuan guru dari $41,46 \%$ menjadi $17,07 \%$ jadi terdapat penurunan $24,39 \%$. Hal ini menunjukkan bahwa siswa tidak tergantung kepada guru, justru dapat berinteraksi antra siswa yang satu dengan yang lain, baik dari teman kelompok maupun antar kelompok.

Hasil-hasil yang diperoleh dari beberapa temuan ini menunjukkan bahwa kemampuan komunikasi matematika memberikan kesempatan kepada siswa untuk mengembangkan kemampuan mengkomunikasikan ide melalui bahasa dan simbol untuk memecahkan suatu masalah matematika. Dengan kata lain situasi masalah yang menarik, menantang, dan kontektual dapat menginspirasikan para siswa mengembangkan ide-ide kreatif baik individual maupun kelompok untuk mengajukan atau membuat soal matematika dengan tingkat kompleksitas yang beragam. Berdasarkan temuan ini terungkap bahwa kemampuan komunikasi matematika dapat meningkatkan prestasi belajar matematika siswa.

\section{PENUTUP}

\section{Kesimpulan}

Berdasarkan hasil analisis dan pengujian hipotesis di atas menunjukkan bahwa terdapat pengaruh yang positif dan signifikan antara kemampuan komunikasi matematika dengan prestasi belajar matematika siswa. Dengan semakin tinggi kemampuan komunikasi matematika siswa maka semakin tinggi pula prestasi belajar matematika siswa kelas VIII semester genap SMP Wijayakusuma Jakarta.

\section{Saran}

Berdasarkan hasil penelitian ini maka saran dan harapan yang bisa peneliti sampaikan yaitu guru dapat lebih mengembangkan profesionalnya dalam mengajar sebagai upaya mewujudkan pembelajaran yang berpusat pada siswa dalam sistem mangajar sehingga berpengaruh pada peningkatan kemampuan komunikasi matematika siswa.

\section{DAFTAR PUSTAKA}

Ahmadi, A. dan Widodo, Supriyono. 2004. Psikologi Belajar. Jakarta: PT. Rineka Cipta. Arifin, Z. 2009. Evaluasi Pembelajaran Prinsip Teknik Prosedur. Bandung: PT. Remaja Rosdakarya.

Armiati. 2003. Komunikasi Matematis dan Pembelajaran Berbasis Masalah. Seminar Nasional Matematika. Bandung: Universitas Katholik Parahyangan.

Fathani, A. H. 2009. Matematika Hakikat dan Logika. Yogyakarta: Ar-Ruzz Media.

Hanun, F. 2009. Pengaruh Kemampuan Komunikasi Matematika Terhadap Hasil Belajar Matematika Melalui Metode Think-Talk-Write. Jurnal Penelitian Matematika, 7 (2), 99-116.

Muliawan, J. U. 2012. Menyulap Siswa Kaya Prestasi di Dalam dan Luar Sekolah. Yogyakarta: FlashBooks.

Mulyana, D. 2007. Ilmu Komunikasi Suatu Pengantar. Bandung: PT. Remaja Rosdakarya. 
Musfiqon, H.M. 2012. Pengembangan Media dan Sumber Pembelajaran. Jakarta: PT. Prestasi Pustakaraya.

Ratumanan, T. G. 2003. Komunikasi Matematika: Tinjauan pada Model PISK dan Model PL. Buletin Pendidikan Matematika. Ambon: FKIP Universitas Pattimura. Slameto. 2003. Belajar dan Faktor-faktor yang Mempengaruhinya. Cetakan V. Jakarta: PT. Rineka Cipta.

Suriasumantri, J.S. 2005. Filsafat Ilmu Sebuah Pengantar Populer. Jakarta: PT. Pustaka Sinar Harapan.

Syaban, M. 2009. Menumbuhkembangkan Daya Matematis Siswa. http://educare.efkipunla.net/index.php?option=com_content\&task=view\&id=62\& Itemid=7. 1 Oktober 2009.

Tammi, H.P. 2010. Pengaruh Kemampuan Komunikasi Matematika Terhadap Hasil Belajar Matematika. Skripsi. Tidak dipublikasikan. Jakarta: Universitas Islam Negeri.

Tirtarahardja, U. 2005. Pengantar Pendidikan. Cetakan II. Jakarta: PT. Rineka Cipta. 